\title{
腰椎々間板症の手術治療と術後成績
}

$\begin{array}{cccccc}\text { 熊本赤十字病院整形外科 } & & & & \\ \text { 平 良 } & & \text { 誠・米 } & \text { 満 } & \text { 弘 } & \text { 之 } \\ \text { 中 根 } & \text { 惟 } & \text { 武・川 } & \text { 島 } & \text { 重 } & \text { 明 } \\ \text { 中 島 } & \text { 英 } & \text { 親・林 } & & & \text { 茂 }\end{array}$

\section{Results of Surgical Treatment for Lumbar Disc Lesion}

by

\author{
M. Taira, H. Yonemitsu, N. Nakane, S. Kawashima, \\ H. Nakashima and S. Hayashi \\ Department of Orthopedic Surgery, Kumamoto \\ Red-Cross Hospital, Kumamoto
}

The total of operations for lumbar disc lesion in the last four years was brought up to 61 cases. anterior approach was done in 40 cases and posterior approach was take in 21 cases.

Follow-up study was carried out in 49 cases clinically and roentgenographically.

The results of operative treatment by anterior approach are classified as excellent 16 cases, good 13 cases, fair 1 case and poor 0 case. On the other hand, the results in posterior approach revealed excellent results in 6 , good in 5 , fair in 2 , and poor in 0 .

\section{はじめに}

腰椎々間板症は，椎間板の変性と機能破綻を主体と する一連の腰痛疾病群を意味する.1934 年, Mixter and Barr による椎間板へルニア摘出の報告以来, 脊 椎外科のめざましい進歩とともに椎間板の病態が明確 となり，腰椎々間板症の概念む確立されるに至った。

我々もこの概念に従い, 過去約 4 年間に 61 症例に 手術を施行し，短期成績ではあるが良好な成績をおさ めている. 手術法として, 前方及び後方法の両者を採 用し，それぞれの適応に基づき，長所，短所を補い合 い成績の向上飞努めている. 今回, 過去 4 年間の症例 を追跡調査し，治㞠成績を検討した．多少の知見をえ たのでこてに報告する.

\section{方法および結果}

昭和 50 年 5 月開院以来, 昭和 54 年 2 月までの過去 3 年 10 力月間の 手術症例は前方法 40 例, 後方法 21 例, 合計 61 例であり, 男女比は 2 対 1 である（表 $1-$ 1). 手術時年令は 12 才から 62 才, 平均 34.2 才であ
り（前方法平均 33 才, 後方法平均 38 才), 年代別で は20才台から 40 才台が殆んどである（表 $1-2$ ).

表 $1-3$ の如く, 疾患別分類ではへルニアが 50 症例 と 8 割以上をしめている. 分離症症例は，いずれも当 該椎間板或いは隣接椎間板にヘルニアを伴った症例で ある. 元り症 8 例を除く 53 症例の障害レベル別内訳 は表 $1-4$ の如く, $\mathrm{L}_{4-5}$ が 32 例之最む多い. 1 椎間 障害が 42 例， 2 椎間障害が 11 例であった，我々は前 方法として腹膜外路法による椎間板切除術, 前方椎体 固定術（以下 E.P.D. と略す）を採用している. 後方 法は殆んどが partial laminectomy である。迈り 症に対して，最近は Meyerding II 度以上の症例で は，大木式 Wire reduction device にて整復を計 った後， 2 次的に E.P.D. を施行するととを原則とし ている(表 2).

評価方法としては，今迄に幾多の報告をみるが，今 回我々は表 3 の如く腰部症状, 社会復帰状況, 坐骨神 経痛の有無, 神経症状の残存, 自覚的満足度の 5 項目 （各 20 点配点）につき評価を行い, 80 点以上を $\mathrm{ex}$ cellent, 50 点以上を good, 30 点以上を fair, 30点 
表 1-1 症

例

\begin{tabular}{|c|c|c|c|}
\hline & 前 方 法 & 後方 法 & \\
\hline 全 & 24 & 17 & 41 \\
早 & 16 & 4 & 20 \\
\hline 計 & 40 & 21 & 61 \\
\hline
\end{tabular}

表 1-2 手術 時 年 令

\begin{tabular}{|c|r|r|r|}
\hline & 男 & 女 & 計 \\
\hline $11 \sim 20$ & 4 & 1 & 5 \\
$21 \sim 30$ & 15 & 5 & 20 \\
$31 \sim 40$ & 9 & 8 & 17 \\
$41 \sim 50$ & 11 & 3 & 14 \\
$51 \sim 60$ & 1 & 3 & 4 \\
$61 \sim 66$ & 1 & & 1 \\
\hline 計 & 41 & 20 & 61 \\
\hline
\end{tabular}

手術時年令 12 才 62 才

平均年令 34.2 才

表 1-3 疾 患別 分 類

\begin{tabular}{|l|c|c|}
\hline & Ant. & Post. \\
\hline Herniation & 31 & 19 \\
Lysis $\oplus$ herniation & 3 & 0 \\
Listhesis & 6 & 2 \\
\hline
\end{tabular}

表 1-4 Level of lesion

\begin{tabular}{|l|r|r|r|}
\hline & Ant. & Post. & 計 \\
\hline L 23 & 1 & 0 & 1 \\
L 34 & 0 & 0 & \\
L 45 & 23 & 9 & 32 \\
L 5 S & 1 & 8 & 9 \\
L 34 L 45 & 3 & 1 & 4 \\
L 45 L 5 S & 6 & 1 & 7 \\
\hline 計 & 34 & 19 & 53 \\
\hline
\end{tabular}

以下を poor とした. 予後調査に応じた 49 例のうち, 術後 4 力月以上を経過せる前方法 30 例, 後方法 13 例 の成績を表 4 亿示す. 前方法では優 $53 \%$, 良 $43 \%$, 可 $3 \%$ ，不可は全くなく優良合わせて $96 \%$ あある.

また後方法では不可が $15.4 \%$ 前方法に比しやや多 いが，優良以上は $84.5 \%$ と良好な成績を示している.

術前レ線における椎間板の狭小化及び不安定性之術 式の関係は, 図 1-1の如くであり, 不安定性を有す る症例には原則として前方法を first choice として いる.

術前の myelogram 所見と手術成績の相関では,
表 2 手 術 法

前方法

1. 腹膜外椎間板切除術

前方椎体固定術 (E.P.D)

2. Wire reduction E.P.D

後方法

1. Partial Ia minectomy (Love法を含む) 15

2. Laminectomy

3. Osteoplastic hemilaminectomy

4. Laminectomy with fusion

5. 分離椎弓切除術

表 3 諨 価 基 準

I 腰部症状

1. 腰が曲りにくい

2. 腰部脱力感, 压迫感あり

3. 仕事をすると波れる

4. 同一姿勢が長時間不能

5. 下肢がしびれる

6. 長く歩くと腰沉こたえる

7. 長く歩くと下肢脱力感の為歩行困難となる

8, 走れない

9. 乗物に乗ると腰にひびく

10. 季節の変り目に腰痛あり 各項目につき 2 点減点

II 社会復㷌状況

1. 健康時と同様仕事可能

年梯任事可能

2. やや愁訴はあるも日常生活に支障なく 仕事が可能

3. 改善をみ, 日常生活および仕事も何と 加可能

4. 日常生活に支障をきたし，仕事も不能

III 坐骨神経痛

1. 全く疼痛な乙

2. 軽度疼痛あり

3. 改善する屯疼痛加なり残存

4. 不変

5. 悪化

20 点

IV 神経症状

1. Lasegue

2. 反 射

3. 知 覚

4. 筋 力

a 全く正常

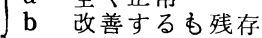

$\left\{\begin{array}{lll}\text { c } & \text { 不 変 } \\ \text { d } & \text { 悪 化 }\end{array}\right.$

15
1
2
1
2

$\mathrm{V}$ 自覚的満足度

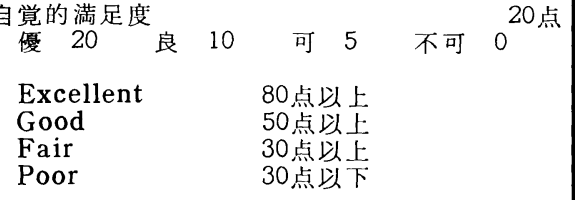

表 4 手 術 战 績

\begin{tabular}{|l|c|l|l|}
\hline & 前方法 & 後方法 & \\
\hline Excellent & $16(53 \%)$ & $6(46 \%)$ & $22(51.2 \%)$ \\
Good & $13(43 \%)$ & $5(38.5 \%)$ & $18(41.9 \%)$ \\
Fair & $1(3 \%)$ & $2(15.4 \%)$ & $3(6.9 \%)$ \\
Poor & 0 & 0 & 0 \\
\hline
\end{tabular}




\section{椎間板のレ線所見と手術法}

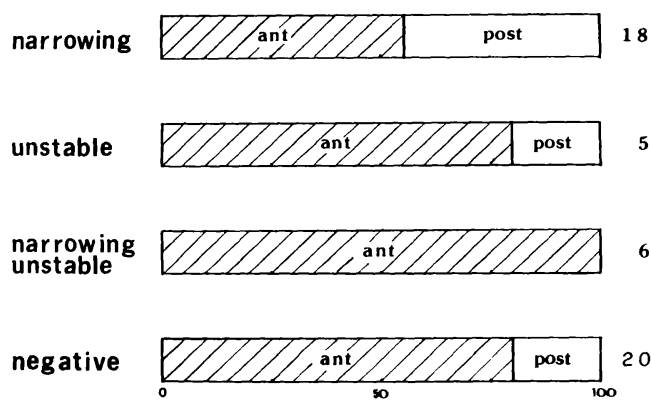

図 1-1

\section{Myelogram と手術成模}
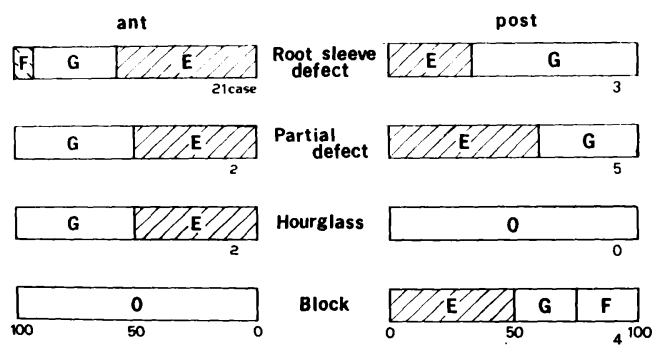

図 1-2

根虽異常のような軽度欠損例で後方法より前方法に優 の割合が多い，砂時計様狭窄を示す正中ヘルニアは前 方法の良い適応と考えている．また完全ブロックを示 す症例は全例後方法にて手術を行っている（図 1 $2)$.

前方固定術の骨癒合率は, ヘルニア症例で 1 椎間手 術では 22 例中 1 例の瘉合不全を認め癒合率 $95.5 \%$ で ある. 2 椎間固定では $87.5 \%$ であり，逐り症では 60 \%である．また，移植骨のつぶれをへルニア症例で 2 例, 迈り症で 2 例みている. 骨癒合不全例でも異常可 動性は認めず，手術成績との相関は認めがたい.

図 $1-3$ は $\mathrm{L}_{4-5}$ 固定例の術後の椎間板可動域を示 したものである. 外固定除去後, 次第に各椎間ともに 可動域は增加し, 術後 1 年から 1 年半の間に正常可動 域に復することが 分かる. また全可動域は 全例低下 し, 非固定椎間部にての可動域増大を認めるも, 固定 直上椎間或いは直下椎間のいずれがょり代償するか は，つかみえなかった．また隣接椎間板の変化も見い
術后の椎間板可钦域

$\mathbf{L}_{45}$ 固定例

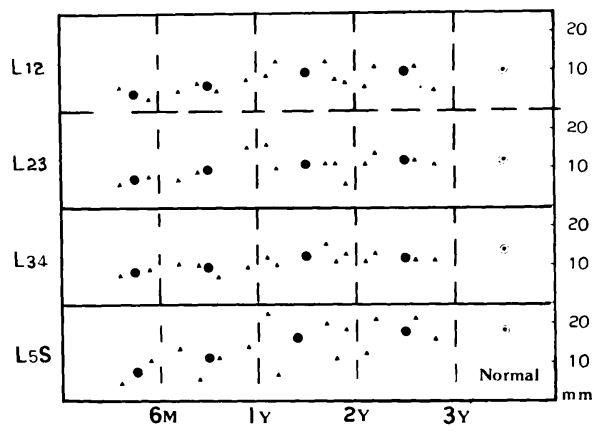

図 1-3

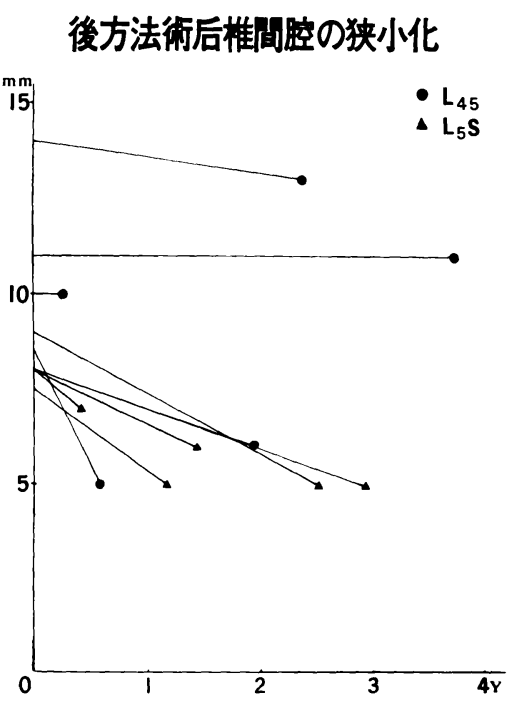

図 1-4

だしえなかった．いずれも短期 follow up のためと 考えられる。

後方法術後の椎間腔の狭小化を経年的にみると, 図 1-4 の如く 2 年以上経過して椎間板の高さが不変な 例は $\mathrm{L}_{4-5} 1$ 例であり, $\mathrm{L}_{5} \mathrm{~S}$ 症例の全例, $\mathrm{L}_{4-5}$ 症例 の $60 \%$ \%狭小化傾向を示している.

合併症は, 後方法では皆無であるが, 前方法では血 栓性静脈炎 1 例, 尿管狭窄 2 例, 血清肝炎 2 例, 肺炎 1 例であり, 術中, 術後の充分な注意が必要である.

代表的症例を示す. 図 $2-1$ は 26 才男の $\mathrm{L}_{4-5}$ ヘル 二ア症例である. 術直後と 2 年 10 力月 経過後のレ線 を比較すると, 移植骨は椎体後縁まで伸び完全に椎体 
E. P. D. L45 Hernia.

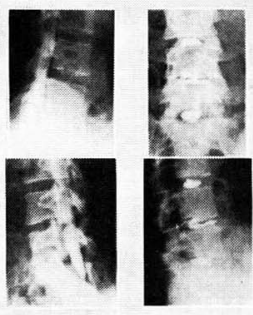

Myelo

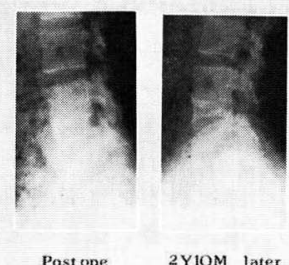

図 2-1

Wire reduction

E. P. D.

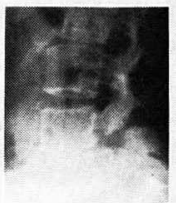

Preope

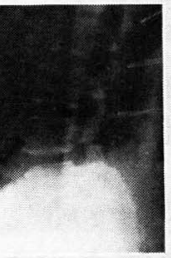

Wire reduction

\section{$\mathrm{L}_{4}$ listhesis}

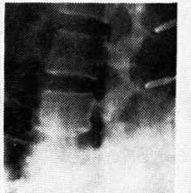

Wire reduction E. P. D.

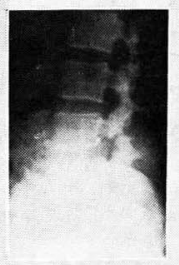

Postope $6 \mathrm{M}$

図 2-2

間癒合が得られている.眓 $2-2$ は 38 才女の迈り症 例である. 左上の術前レ線では $\mathrm{L}_{4}$ 过り $11 \mathrm{~mm}$, 立 り率 $27.5 \%$ が wire reduction 後, 左下図の如く完 全整復位を得ている. 右上网は E.P.D. 直後, 右下は 術後 6 力月現在のレ線写真である. rebound が みら れている.

\section{考察}

腰椎々間板症，なかでも腰椎々間板ヘルニアの手術 成績の報告は数多く, その術式屯前方法, 後方法, 固 定併用，非固定等さまざまである，Roaf は椎間板摘

出のみにて 430 例中 $91 \%$ に良好な結果を得たと, ま た桐田も 626 例の術後成績において $90.4 \%$ が全治で あったと報告している。一方， Barr， O'Connel, Naylor らは椎弓切除術, 部分椎弓切除術後, 神経症状 は消失しても腰痛が高率に残存することを指摘してい る. Love, Howarth, 本邦に扔いては浦田, 森らが 非固定群之固定群の手術成績を比較し, 固定群の方が 10〜20\%優秀であったと報告している. 一方前方椎体 固定術も, 経腹膜的, 腹膜外路法の差はあれ, Harmon $93 \%$, Freebody $91 \%$, 鈴木 $96 \%$, 井上 93.4 \%, 中野 $100 \%$ 之良好な成績を治めている，殊に Hodgson は腰痛の改善率を $94 \%$ 亿みたと報告してい るが, Sacks, Staffer らは, Salvage 手術にのみ行 うべきであるとしている，以上のように，腰椎々間板 ヘルニアに刘する手術術式の優劣は，にわかには決め 難い. しかしながら, 症例数も少なく短期成績ではあ るが，我々の術後 4 力月以上経過せる前方椎体固定術 30 症例の成績は, 優 $53 \%$, 良 $43 \%$, 可 $3 \%$ 之不可 症例はなく，極めて良好な成績である。その骨瘉合率 に打いてもへルニア症例の 1 椎間固定で $95.5 \%$ ，2 椎間固定で $87.5 \%$ であり, Freebody $90 \%$, Harmon $98 \%$, Hodgson $84.6 \%$, 干葉大学井上の報告 では 1 椎間手術 $95 \%$ ，2 椎間手術で $87 \%$ と比しあま り差は認めない，癒合不全の原因としては，鈴木，井 上，渡辺らが述べている如く，母床之移植骨の不適合 であり, 母床の充分なる開さく, 移植骨の形状に留意 し，技術的向上を計る必要がある.

後方法 13 例の術後成績屯優 $46 \%$, 良 $38.5 \%$, 可 $15.4 \%$ \%゙り，優良合わせて $84.5 \%$ 之良好な結果を えている，というのも，上線上椎間板の狭小，不安定 性を示し，Discogram 上も変性変化を認める症例に は原則として前方法を採用しており， myelogramに て完全ブロックを示すもの，馬尾神経とへルニアとの 癒着を思わせるものや，春椎管狭窄をともなう症例 等, 前方法の適応外に対し，後方法を応用しているか らとあいえる.

浜野の実験結果，上屋のヘルニア症例における前方 椎体固定術の遠隔成績でも, 腰椎柱, 隣接椎に及ぼす 影響は軽微であると報告しているように，我々の症例 においても隣接椎間高の狭小化，可動域の著明低下ま たは増大，之り，骨棘形成等は近隔成績ではあるが， 全くみていない.

ところが一方, 後方法術後においては当該椎間板の 
狭小化が， $\mathrm{L}_{5} \mathrm{~S}$ 症例で $100 \%, \mathrm{~L}_{4-5}$ 症例で $60 \%$ にみ られており, これは明らかに椎間板の変性変化を示す あのといえよう. Simmons, 浦田らが椎間関節 の関 節症の発生, 不安定椎の出現が腰痛の原因であると述 べているように，長期 follow up 時に問題となると ころである.

$$
\text { 結語 }
$$

1. 術後 4 力月以上を経過せる腰椎々間板症 43 症 例を独自の評価基準にて評価した。

2. 術後成績は, 前方法では優 $53 \%$, 良 $43 \%$, 可 $3 \%$, 後方法では優 $46 \%$, 良 $38.5 \%$, 可 $15.4 \%$ で あり, 両法ともに不可症例は認めていない，

3. 前方椎体固定術の骨癋合率は, ヘルニア症例の 1 椎間固定で $95.5 \%$ ，2椎間固定 $87.5 \%$ ，之り症で は $60 \%$ \%でった.

4. 後方法術後, $\mathrm{L}_{5} \mathrm{~S}$ 例で $100 \%, \mathrm{~L}_{4-5}$ 例で $60 \%$ に椎間控の狭小化傾向を示した．乙れは明らかに椎間 板変性を物語り, 椎間関節の変化と共に腰痛の原因と なりうる。

5. 我々は, 腰椎々間板症に対し, 前方椎体固定術 を標準的術式として採用し, 術中, 術後の合併症に留 意を心卦け, 安定した良好な成績を得ている.

\section{文}

\section{献}

1) Barr, J. S.: J. Bone Joint Surg., 33-A : 633, 1951.

2) Freebody, D. et al.: J. Bone Joint Surg., 53-B: 617, 1971.

3）浜野恭之：日整会誌，42：1089，1968.

4) Harmon, P. H.: Clin. Orthop., 18: 169, 1960.

5) Hodgson, A. et al.: Clin. Orthop., 56: 133, 1968.

6) Howarth, B.: J. Bone Joint Surg., 46-A : $1485,1964$.

7）井上駿一：災害医学, 18:76, 1975.

8）桐田良人：整形外科，13:740, 1962.

9）桐田良人：災害医学, 18: 54, 1975 ,

10）松井宣夫：日整会誌，48：781，1974.

11) 森 健躬：整形外科, 18：43，1967.

12）村田忠雄：災害医学, 21：1311, 1978.

13) 中野昇：整形外科, $23: 567,1972$.

14) Naylor, A.: J. Bone Joint Surg., 56-B 17, 1974.
15) O'Connel, J. E. A.: J. Bone Joint Surg., 33-B: 8, 1951.

16) Roaf, J.: Am. J. Surg., 97: 388, 1959.

17) Sacks, S.: J. Bone Joint Surg., 47-B : 211, 1965.

18）鈴木次郎：日整会誌，41：454，1967.

19）土屋恵一：日整会誌，47：731，1973.

20）辻 陽雄：示説腰椎々間板障害, 1972。金原出 版, 東京.

21）浦田固志：整形外科，18:37，1967。

22) 浦田固志：整形外科，18: 115，1967。

23）渡讱良彦：日整会誌，33：21，1959.

質 問

九大整形 丸井 俊一

(1) $27 \%$ 之り例で wire reduction を行っている が，乙の程度のものであれば，一期的治療で充分な整 復之, 前方固定が出来ると思います。

wire reduction の必要性があるのか否か.

回 答熊本赤十字病院 平良 誠

九大の丸井先生の「その程度の之りでは Wire reduction を行う必要はないのでは」という質問に対 L:

我々は Meyerding II 度以上の之りに対し, Wire reduction を行っている. その方が一期的に前方法 で行うより之りの残存が少いように思う．どの程度の 方りから Wire reduction を行うか, 或いは re bound の問題は今後の課題之考えている.

回 答熊本赤十字病院 平良 誠

(1)「ヘルニアに対し前方法を first choice とす るのはどうであろうか.」の質問に対し：

前方法では腰痛の残存率が少く，長期的に安定した 成績が得られると考えられる，後方法より手術侵蝈が 大きいのは否めない。

(2)「 $\mathrm{L}_{5} \mathrm{~S}$ の前方侵入は，経腹膜的の方が良いので は」という質問に対し：

腹膜外路法でも，血管の処理をうまく行えば，何ら 合併症もなく，問題ないと考えている．また，開腹と いうことは患者にとり，かなりの侵襲となる.

(3)「椎間板の狭小化と, nucleus の摘出量 との 関係は」:

てれに関しては，今回調査していない. 